\title{
Analisis yuridis-normatif terhadap peran dan tindakan telemarketing dalam transaksi digital
}

\author{
Indah Rahmawati
}

Indah Rahmawati; Fakultas Hukum Universitas Airlangga; Jl. Dharmawangsa Dalam Selatan; Surabaya; 60286; Jawa Timur; Indonesia.

\section{ARTICLEINFO}

Article history:

Received 2020-01-19

Received in revised form

2020-03-06

Accepted 2020-04-01

\section{Kata kunci:}

Peran dan Tindakan;

Telemarketing; Transaksi Digital.

\section{Keywords:}

Roles and Actions; Telemarketing;

Digital Transactions.

DOI: https://doi.org/10.26905/ idjch.v11i1.4047.

\section{How to cite item:}

Rahmawati, I. (2020). Analisis yuridis-normatif terhadap peran dan tindakan telemarketing dalam transaksi digital. Jurnal Cakrawala Hukum, 11(1), 60-70. doi:10.26905/idjch.v11i1.4047.

Corresponding Author:

* Indah Rahmawati.

E-mail address: indahrhmwti@gmail.com

\begin{abstract}
Abstrak
Perkembangan kebutuhan akan hukum di era digital menjadi suatu tuntutan baru. Pada era revolusi industri 4.0 lebih banyak meninggalkan cara-cara konvensional dan beralih menggunakan metode digital. Asas dan nilai hukum memang masih bersifat tetap, akan tetapi apabila metode-metode baru tidak diatur lebih lanjut akan menimbulkan masalah dalam praktik dunia hukum. Salah satu yang menjadi permasalahan adalah telemarketing. Metode telemarketing sudah banyak digunakan dalam beberapa tahun di dunia perekonomian Internasional. Marketing memang menjadi ujung tombak keberhasilan dari suatu perusahaan. Masalah mulai timbul ketika telemarketing disalahgunakan dengan menggunakan celah-celah tertentu. Penelitian ini menggunakan metode yuridis-normatif dengan pendekatan norma dan analisis teori. Hasil dari penelitian ini mengungkap bahwa dalam pemidanaan akan lebih kompleks jika berhadapan dengan perusahaan karena sosok badan hukum pada dasarnya berbeda dengan orang individu dalam hal pertanggungjawaban. Pada ranah keperdataan masih banyak konsumen yang dilindungi oleh normanorma yang ada di Indonesia melalui lembaga otoritas jasa keuangan dan penyelesaian sengketa oleh Pengadilan. Beberapa masalah keperdataan disebabkan karena adanya penyalahgunaan keadaan oleh perusahaan yang mengelola jasa keuangan.
\end{abstract}

\section{Abstract}

The development was needed some law in about digital regulation. At the era of industrial revolution 4.0 abandoned more conventional methods and has switched to used digital methods. The principles and values of law are indeed permanent, but if new methods are not annulled further they will cause problems in the practice of the legal world. One of many problem is telemarketing. The telemarketing method has been widely used in recent years in the economy sectoral. Marketing is indeed the spearhead of the success of a company. Problems begin to arise when telemarketing 


\section{Jurnal Cakrawala Hukum, Volume 11 No. 1 April 2020 \\ ISSN PRINT 2356-4962 ISSN ONLINE 2598-6538}

is misused by using certain gaps. This research uses a juridical-normative method with norm approach and theory analysis. The results of this study reveal that criminal prosecution will be more complex when execute with companies because the figure of a legal entity is fundamentally different from individuals in terms of accountability. In the realm of civilization many are protected by existing norms in Indonesia through financial service authority institutions and dispute resolution by the Court. Some civil problems are caused by Misbruik van Omstadigheden of the companies that manage financial services.

\section{Latar Belakang}

Kehadiran Undang-Undang Republik Indonesia Nomor 11 Tahun 2008 tentang Informasi dan Transaksi Elektronik (Undang-Undang ITE), yang seharusnya melindungi hak konsumen justru menjadi pedang bermata dua yang sisi lainnya mencederai konsumen ketika disalahgunakan oleh orang yang tidak bertanggungjawab. Banyak masalah mulai muncul ketika korporasi memanfaatkan Undang-Undang ini sebagai tameng legalitas perbuatannya. Jurnal Nabhila Palupi Paramarta dalam penelitiannya memberikan keterangan bahwa banyak masyarakat yang terjebak kepada "modus" asuransi yang menggunakan telemarketing. Ketidaktahuan masyarakat akan perekaman percakapan sebagai bentuk awal kontrak dan menjadi alat bukti. Implikasinya setiap bulan konsumen harus keluar sejumlah uang setiap bulannya untuk membayar asuransi yang pada kenyataannya tidak menginginkan atau membutuhkan.

Proses marketing merupakan tombak keberhasilan dari perusahaan. Oleh karena itu sering sekali digunakan. Perusahaan baik di sektor swasta maupun Badan Usaha Milik Negara (BUMN) sudah banyak yang menggunakan jasa telemarketing. Posisi telemarketing dianggap masih relevan dengan didukungnya sarana dan prasarana berbasis informasi-teknologi daripada hanya sekedar menyebarkan brosur dan door to door menjemput konsumen. Data transaksi yang seharusnya rahasia ternyata banyak digunakan pada antar perusahaan untuk menggaet konsumen.
Masalah tersebut merupakan kekaburan norma atas perlindungan konsumen (nasabah) dan perjanjian yang dilakukan oleh bank. Perjanjian pada dasarnya dapat menggunakan pasal 1320 mengenai sah atau tidaknya suatu perjanjian, tetapi dengan dimanfaatkannya Undang-Undang ITE maka syarat subyektif dari suatu perjanjian menjadi kabur. Kekaburan ini karena untuk dapat sepakat dan cakap tidak perlu dibuktikan secara tertulis pada umumnya, dan melalui asas lex priori derogat lex posteriori korporasi menjadi sangat leluasa.

Pada saat terjadi percakapan masyarakat dengan telemarketing, hanya dengan mengucapkan kata "ya" yang diasumsikan setuju atas perjanjian. Tindakan ini berusaha menyimpangi syarat sahnya perjanjian berupa sepakat dalam pasal $1320 \mathrm{KUH}$ Perdata. Peluang dan situasi semacam ini banyak telemarketing memanfaatkan situasi dan kondisi semacam ini. Bahkan berdasarkan pengaduanpengaduan konsumen, hanya dengan mengangkat telephone dari telemarketing sudah bisa membebankan biaya. Bukti awal perjanjian bukan merupakan bukti otentik yang kuat karena tidak dibuat oleh pejabat yang berwenang.

\section{Metode}

Metode penelitian merupakan suatu cara dalam mendapatkan data dan menganalisis. Penelitian tentang telemarketing ini menggunakan yuridisnormatif. Penelitian yuridis- normatif adalah bentuk kegiatan penelitian ilmiah yang menggunakan bahan kepustakaan dan konseptual (Ibrahim, 2007). 


\section{Analisis yuridis-normatif terhadap peran dan tindakan telemarketing dalam transaksi digital}

Indah Rahmawati

\section{Pembahasan}

\section{A. Kedudukan telemarketing}

Definisi normatif dari Peraturan Perundangundangan memang tidak memberikan secara tertulis dari telemarketing. Jika dikaji kedudukannya telemarketing ini merupakan sub bagian atau termasuk salah satu organ dari pengertian Pelaku Usaha Jasa Keuangan (PUJK). Pelaku ini dapat berupa bank, investasi, saham, gadai atau yang dipersamakan dengan itu yang diakui oleh UndangUndang. Telemarketing merupakan bagian dari divisi marketing dan Public Relation dari perusahaan yang berperan dalam memasarkan produk atau jasa keuangan dari perusahaa tersebut. Perumusan telemarketing ini sejatinya dapat dibedakan dengan call center atau call service karena sifat marketing lebih mengarah kepada penawaran bukan permintaan. Rumusan Pasal 1 Peraturan Otoritas Jasa Keuangan Nomor: 1/POJK.07/2013 berbunyi bahwa;

"Pelaku Usaha Jasa Keuangan adalah Bank Umum, Bank Perkreditan Rakyat, Perusahaan Efek, Penasihat Investasi, Bank Kustodian, Dana Pensiun, Perusahaan Asuransi, Perusahaan Reasuransi, Lembaga Pembiayaan, Perusahaan Gadai, dan Perusahaan Penjaminan, baik yang melaksanakan kegiatan usahanya secara konvensional maupun secara syariah"

Perusahaan yang bergerak di bidang jasa keuangan memiliki izin untuk beroperasi dimana pada bagian pemasaran menyediakan sarana untuk memasarkan melalui metode perusahaannya, salah satunya adalah telemarketing. Rumusan yuridis pada dasarnya mengatur hal-hal yang bersifat pokok.

Perumusan yuridis lebih mengarah kepada essensi suatu nilai dan perbuatan sehingga ke depan seandainya istilah telemarketing ini berubah dengan apapun itu hukum tetap bisa melihat ke dalam satu essensi yang sama.

\section{B. Pendekatan kasus (case approach)}

Kasus yang pertama diambil dari salah satu asuransi yaitu AXA Mandiri. Penelitian Robby dengan implementasi Undang-Undang ITE dan Perlindungan Konsumen ternyata belum mampu menjawab penyelesaian secara cepat dampak dari telemarketing ini. Jalur-jalur penyelesaian sengketa ternyata cukup panjang seperti jalur perdata pada umumnya. Bagi konsumen yang sudah mengalami kerugian materiil akan menambah kerugian secara waktu karena terdapat birokrasi yang panjang.

Berdasarkan situs https://id.tellows.net, banyaknya pengaduan telemarketing adalah dengan melalui metode pemaksaan. Proses pemaksaan ini dilakukan dengan tidak memberikan resiko-resiko atas penggunaan jasa perusahaan tersebut. Pasal 4 huruf C Undang-Undang Perlindungan Konsumen sudah memberikan pengaturan dengan jelas bahwa segala resiko sudah harus diberikan oleh marketing sebelum adanya persetujuan.

Kasus kedua berasal dari pelanggan tv kabel dan internet. Sebagai salah satu pelanggan dari televisi dan internet berbayar pernah suatu waktu di hubungi dengan penawaran paket yang lebih besar dengan harga yang lebih mahal. Konsumen sempat menolak namun tagihan di bulan berikutnya membengkak sesuai tarif yang ditawarkan tersebut. Padahal sudah jelas bahwa dasar melakukan persetujuan adalah pada pasal 5 jo pasal 11 UU ITE dengan melalui rekaman.

Permasalahan utama dalam kasus telemarketing ini adalah penawaran kartu kredit. Pemakaian kartu kredit merupakan gerbang utama dalam transaksi keuangan bagi telemarketing. Ketidakhati-hatian konsumen merupakan celah yang sangat rawan dalam kepemilikan kartu kredit. Dampak kepemilikian kartu kredit memiliki multiple effect yang mungkin tidak terduga oleh konsumen. Oleh karena itu seringkali pihak perbankan memaksakan kepemilikan kartu kredit kepada konsumen, bank pemerintah maupun bank swasta. 


\section{Jurnal Cakrawala Hukum, Volume 11 No. 1 April 2020}

ISSN PRINT 2356-4962 ISSN ONLINE 2598-6538

Kartu kredit dengan dalih gratis administrasi beberapa bulan digunakan untuk mengikat nasabah. Tujuan dari perbuatan tersebut adalah meningkatkan laba atau profit dengan mengambil bunga atas penggunaan kartu kredit. Sekalipun tidak digunakan sekali lagi bank tetap untung dengan biaya administrasi yang dibebankan kepada konsumen setelah promosinya habis. Namun permasalahan utama justru pada penggunaan kartu kredit ini. Para pemilik kartu kredit sebetulnya justru menjadi sasaran utama dalam perjanjian elektronik pencairan pendanaan. Sudah banyak komplain-komplain yang beredar sebab hanya dengan memberikan beberapa nomor kartu kredit sudah dapat membebankan biaya kepada pengguna. Hal inilah yang menjadi celah dalam modus penipuan melalui kartu kredit. Bahkan terdapat bank yang memaksa, sampai mengirim kartu kreditnya dengan bentuk fisik ke alamat rumah nasabah sekalipun nasabah tidak menginginkan atau bahkan menyetujuinya. Nasabah sempat komplain tetapi jawaban dari bank mengatakan bahwa sepanjang kartu tersebut tidak sempat dipergunakan (digesek) maka tidak akan aktif.

Analisis dalam multiple effect selanjutnya dari perbankan adalah penawaran jasa kepada pihak ketiga. Seringkali bank bekerja sama dengan beberapa perusahaan lain untuk membentuk proses berbagi keuntungan. Salah satunya adalah perusahaan asuransi, baik yang dikelola atas nama bank itu sendiri sebagai anak perusahaan ataupun benarbenar berasal dari sektor swasta.

Kebocoran data menjadi sangat rentan terjadi ketika sudah bekerja sama dengan pihak ketiga ini. Hal ini dapat dibuktikan dengan membuat satu subyek nasabah yang sebelumnya sama sekali tidak mempunyai rekening bank. Nasabah tersebut kemudian membuat rekening untuk keperluan pay roll transfer gaji per bulan yang masuk. Rekening pay roll merupakan rekening yang akan terus dipantau oleh bank. Setelah beberapa bulan pay roll dipastikan berjalan, secara otomatis akan ada banyak nomor-nomor tidak dikenal menawarkan berbagai produk yang berbasis keuangan mulai dari kartu kredit bahkan sampai kepada asuransi. Biasanya rekening pay roll akan menjadi sasaran utama telemarketing karena lebih menjanjikan dalam proses pembayaran dan auto debet.

Beberapa tahun terakhir pembukaan rekening bank mulai kurang transparan dengan tidak menyampaikan bukti salinan kontrak awal rekening pembukaan bank dan dengan tidak disampaikannya resiko-resiko secara holistik. Pada kontrak awal pembukaan rekening ternyata di desain untuk memberikan celah promosi bahwa nasabah bersedia diberikan segala jenis promosi bank dan dari pihak-pihak yang bekerja sama dengan bank baik berupa anak perusahaan maupun pihak ketiga. Pada masa sekarang, posisi nasabah seolah-olah menjadi orang yang yang membutuhkan ketika mengajukan pembukaan rekening terutama bank yang memiliki modal besar. Prinsip keadilan bagi para pihak mulai ditinggalkan.

Perjanjian pokok bank yang disodorkan pada saat pembukaan rekening secara klausulal tertulis bahwa informasi nasabah dapat dibagi kepada anak perusahaannya dan pihak yang bekerjasama dengannya. Standar klausulal tersebut justru berpotensi membongkar informasi yang seharusnya dilindungi. Pihak bank juga tidak pernah terbuka atas informasi yang seperti ini karena situasi yang dianggap menguntungkan bagi badan hukumnya. Intinya selama nasabah tidak memiliki pemikiran kritis bila terjadi kerugian, bukan salah bank. Masalah ini menjadi salah satu perhatian masyarakat dengan adanya kebocoran data nasabah yang dilakukan oleh oknum petugas bank dengan membagikan atau bahkan menjual data nasabah kepada pihak ketiga atau lembaga keuangan lain yang dengan cepat data ini tersebar luas. Dalam kasus tersebut terdapat data dengan jumlah 13 Gyga Byte yang berisi data nasabah prioritas (Raily, 2017). 


\section{Analisis yuridis-normatif terhadap peran dan tindakan telemarketing dalam transaksi digital}

Indah Rahmawati

\section{Kejahatan di bidang ekonomi}

Teori Merton (Merton dalam Hagan, 1985) menganggap bahwa manusia pada dasarnya selalu melanggar hukum setelah terputusnya antara tujuan dan cara mencapainya menjadi demikian besar, sehingga satu-satunya cara mencapai tujuan adalah melalui saluran yang tidak legal. Sifat dasar manusia memiliki kecenderungan untuk melakukan perbuatan melanggar hukum. Pada poin studi kasus dapat dijelaskan bahwa penanggungjawab dalam telemarketing adalah perusahaan penyedia jasa keuangan.

Korporasi yang termasuk dalam kategori White Collar Crime memiliki integrasi sistem yang sangat tertata (Firman, 2015). Sebuah korporasi tidak bekerja sendiri dalam menjalankan segala bentuk usahanya. Bentuk-bentuk kerja sama yang terintegrasi terdiri dari beberapa sektor seperti sesama perusahaan. Salah satunya adalah jual-beli data nasabah bank yang telah beredar di kalangan telemarketing. Bahkan pembuktian pembocoran data akan sedikit kesulitan dalam membuktikan adanya penyebaran informasi nasabah dan konsumen terutama jika jejak digitalnya memang berhasil dihapuskan. Pendapat Merton (1985), mengacu ketika salah satu korporasi melakukan tindak kejahatan dapat pula turut melibatkan beberapa korporasi lainnya. Tuntutan korporasi dalam memajukan perusahaan menjadi salah satu penyebab tentang dilakukannya perbuatan melawan hukum. Kolaborasi antara Pelaku Usaha Jasa Keuangan menyebabkan suatu sistem dengan tujuan melawan hukum.

Tuntutan pertama dan utama yaitu pada sektor ekonomi. Korporasi yang merupakan badan hukum nirlaba tujuan utama adalah menghasilkan laba. Badan hukum dengan jenis ini mempunyai target yang harus dicapai setiap tahun, setiap triwulan bahkan setiap bulannya. Tuntutan ini menyebabkan adanya penekanan-penekanan pada sektor SDM baik dari tingkat direktur sampai kepada karyawan di tingkat lini. Motivasi punish dan reward dengan tidak memandang dampak perbuatan maka akan mempengaruhi keberanian tingkat pelanggaran yang dilakukan. Hal ini juga dipengaruhi dari adanya kenaikan UMR dari tahun ke tahun yang harus disesuaikan. Pilihan yang sulit yaitu dengan merampingkan korporasi atau mengembangkannya. Jika merampingkan, maka di lain pihak akan berhadapan dengan sengketa industrial yang akan membuang biaya dan waktu yang tidak sedikit. Maka pilihan satu-satunya adalah dengan mengembangkannya, oleh karena itu dari target capaian yang harus diraih setiap tahun harus terjadi peningkatan entah bagaimana caranya.

Tuntutan kedua adalah pengembangan kelembagaan. Pengembangan kelembagaan biasanya direncanakan ke dalam rencana strategi yang akan terbagi menjadi beberapa tahun. Tingginya tekanan untuk mengembangkan lembaga dapat memicu faktor kriminogen itu sendiri antara lain melebarnya perluasan atas tanah, pengembangan lahan, bahkan dalam proses-proses perizinan yang berdampak pada lingkungan hidup. Pada proses pengembagannya juga harus meningkatkan pendapatan yang hal ini harus dilakukan oleh sektor pemasaran.

Menurut (Fabermen dalam John Hagan, 1985) ketika sebuah korporasi sudah mendapatkan konsentrasi yang jenuh dari tuntutan korporasi itu sendiri akan menghasilkan sebuah konsep dasar berupa "criminogenic market structure". Istilah ini menyebut adanya suatu tindakan yang menyebabkan tata cara pemasaran dengan cara-cara melawan hukum. Kenyataan yang terjadi dalam suatu korporasi akan mengakibatkan profit setinggi-tingginya dengan cara menjual suatu produk atau jasa yang sangat kecil dengan harga yang mahal. Hasil akhirnya akan bermuara pada penekanan pada tinggi atau banyaknya pemasaran, dengan pelayanan yang sangat sedikit. Perbuatan ini termasuk adanya suatu tindakan kejahatan di bidang ekonomi. Strategi pemasaran yang dilakukan meng- 
akibatkan perbuatan-perbuatan yang sangat memaksa terutama melawan hukum dengan memaksa persetujuan dari calon konsumen, namun pelayanan pasca persetujuan akan sangat sedikit dan mengecewakan. Hal ini banyak terjadi di sektor asuransi, bahkan untuk berhenti membayar atau mengajukan tuntutan kepada perusahaan asuransi menjadi sangat panjang.

Proses yang sangat panjang dalam mengajukan proses gugatan ini sebenarnya sudah di anulir oleh Mahkamah Agung. Mahkamah Agung sebenarnya sudah membuat peraturan kebijakan berupa PERMA Nomor 2 Tahun 2015 tentang Penyelesaian Gugatan Sederhana. Namun, satu hal yang sangat disayangkan adalah PERMA ini tidak berlaku bagi proses peradilan khusus, bukan pada peradilan umum. Kasus telemarketing sudah selayaknya diselesaikan secara prosedur sederhana karena berawal dari tawaran perusahaan, bukan atas permintaan konsumen. Essensi PERMA ini tertuang ke dalam konsideran bahwa di ciptakannya PERMA ini adalah sebagai upaya memberikan kebutuhan keadilan bagi pencari keadilan dengan melalui prosedur penyelesaian sengketa yang lebih sederhana, cepat, dan biaya ringan. Proses perikatan yang sangat sederhana dalam memberikan proses pembayaran sebaiknya diberikan juga peluang untuk dapat digunakan penyelesaian secara cepat. Jika dalam kasus ini sebenarnya konsumen mudah masuk tapi susah untuk keluar dari permasalahan dampak telemarketing.

Praktik penyelenggaraan badan hukum yang pertama kali akan sangat rentan melakukan pelanggaran, hal ini karena terbatasnya sumber daya. Sumber daya yang ada di sini baik sumber daya anggaran, sumber daya manusia, maupun sumber daya sarana. Atas dasar efektifitas dan efisiensi tidak jarang badan hukum melakukan beberapa pelanggaran seperti tidak mencapainya upah pekerja pada UMR atau menggunakan caracara lainnya termasuk perbuatan memaksa pada sektor marketing.
Korporasi atau perusahaan jika dibandingkan obyek individual akan mempunyai proses pembuktian lebih kompleks (Cristopher dalam John Hagan, 1985). Hal ini membuat siapa-siapa saja yang bertanggungjawab menjadi samar. Kekuatan korporasi melalui legal staff membuat paying tersendiri terhadap para pimpinan korporasi. Banyak kasus-kasus korporasi yang bermasalah jutsru mempidanakan karyawan yang berada dalam lini dimana seharusnya penanggungjawab perbuatan ikut dipidana. Pada kejahatan di bidang ekonomi di Indonesia, pada faktanya penegakan memang cukup sulit dilakukan karena berhadapan dengan sebuah korporasi. Dari beberapa studi kasus yang dilakukan, yang berujung pada pidana bukan pada doenpleger (pengambil keputusan atau menyuruh melakukan) tetapi pada pleger atau pelaku sedangkan pada korporasi sendiri hanya sebatas sanksi administratif tanpa mampu menyentuh doenpleger. Hal ini dikarenakan korporasi kurang bertanggungjawab dari pada pelaku kejahatan individual, oleh karena itu korporasi cenderung tidak menjadi perhatian bagi obyek dari aturan yang ada dalam kontrol sosial.

Analisis terhadap teori cristopher tentang pergerakan korporasi menyatakan bahwa mereka yang mempercayai hukum untuk mengikat perusahaan telah gagal memahaminya. Peristiwa perusahaan-perusahaan melakukan tindakan melawan hukum menjelaskan sejumlah alasan. Alasan tentang mengapa ancaman sanksi hukum cenderung kurang memberikan efek yang "diinginkan" dan aturan menjadi tidak berpihak ketika perusahaan adalah targetnya. Bahwa dalam analisis ini menjelaskan dampak aturan yang berlaku dianggap tidak menguntungkan sejalan dengan perusahaan. Faktor-faktor tersebut antara lain terhadap perusahaan misalnya, membatasi hak dan kewajiban, kurangnya kesesuaian antara insentif, karir untuk mencapai puncak pimpinan, dan penghargaan "perusahaan" merupakan kecenderungan badan hukum untuk bergerak sendiri atau melalu- 


\section{Analisis yuridis-normatif terhadap peran dan tindakan telemarketing dalam transaksi digital}

Indah Rahmawati

kan improvisasi terhadap ancaman eksternal yang dalam hal ini terutama hukum. Melalui analisis dari teori cristopher, dengan kedudukan korporasi yang lebih halus dalam melakukan pelanggaran dan motivasi untuk melawan hukum akan membuat korporasi semakin leluasa dalam melakukan pelanggaran. Teknik telemarketing dengan perluasan metode kepada perjanjian merupakan upaya try and error dalam membuat kebebasan berkontrak bagi perusahaan penyedia jasa keuangan.

Beberapa tahun terakhir banyak perusahaan yang hadir dan terkadang dipelopori oleh perusahaan asing yang bergerak di bidang investasi illegal dengan tawaran yang tidak sesuai ketentuan peraturan. Baik dari perusahaan yang benarbenar ada seperti jasa saham sampai pada saham dan investasi abal-abal berbasis ponzi. Skema ini merupakan strategi dalam menjebak konsumen diantaranya menawarkan bunga yang tidak sesuai ketentuan Lembaga Penjamin Simpanan atau perusahaan yang tidak bergerak di bidang semestinya.

Undang-Undang PT memiliki kemiripan standar, hanya berbeda implementasi. Pada klausulal Undang-Undang PT direktur berkewajiban menjalankan tugas dengan itikad baik dan bertanggungjawab penuh. Implementasi yang terjadi adalah yang bertanggungjawab adalah posisi karyawan lini sebagai yang menjalankan perintah. Ada keharusan dalam menjalankan korporasi untuk mengawasi jalannya perusahaan termasuk dalam hal ini penggunaan telemarketing. Metode dan target dari telemarketing minimal jajaran direksi mengetahuinya sekalipun hal tersebut patut diketahui melawan hukum.

\section{Analisis normatif}

Pendekatan pendekatan melalui yuridis normatif dengan melakukan analisis terhadap sumber-sumber hukum positif. Sumber hukum positif di Indonesia yang digunakan dalam penelitian ini adalah undang-undang dan putusan hakim.
1) Putusan Pengadilan Negeri Bandung Nomor 185/PDT/G/2011/PN.BDG dengan Para Pihak Herland Cup Nainggolan dkk sebagai Penggugat vs PT. Asuransi Cigna (T1) dan PT Bank Danamon, Tbk (T2) sebagai tergugat.

Kasus di atas dalam posita yang diberikan oleh pihak penggugat dan putusan hakim tertulis sebagai berikut:

"Bahwa Penggugat adalah nasabah dari Tergugat II sebagai pemegang kartu kredit. Bahwa hubungan Penggugat dengan Tergugat II adalah sangat baik selama ini, kemudian marketing Tergugat I menelepon Penggugat dengan menawarkan produk asuransi yang menguntungkan, untuk masuk asuransi kesehatan. Mula-mula Penggugat menolak tetapi terus dirayu-rayu oleh Tergugat I dengan kata-kata yang manis yang mengatakan bahwa PT. Asuransi Cigna adalah asuransi yang bertaraf Internasional dan bonafit dan selalu diekspos di to dan Korankoran di seluruh Indonesia. Dari bujuk rayu tersebut terpengaruhlah Penggugat karena dikatakan Tergugat I telah bekerja sama dengan Tergugat II sehingga tahui identitas Penggugat termasuk pemegang kartu kredit dari Tergugat II kemudian akibat bujuk rayu tersebut Penggugat masuk dalam asuransikesehatan"

Metode dan modus yang digunakan sebenarnya mengarah pada bujuk rayu yang mengarah pada pasal 368 KUHP tentang rangkaian kebohongan untuk menggerakkan seseorang, hanya unsur obyektif tidak terpenuhi karena menguntungkan di sini berpihak kepada perusahaan. Seperti yang disampaikan dalam teori cristopher, untuk membuktikan pemidanaan dalam kasus korporasi akan sulit. Selain itu, kasus ini mengarah kepada bidang perdata disebabkan adanya "kesepakatan" dalam muara telemarketing tersebut.

Pengadilan Negeri memberikan putusan bahwa tergugat harus membayar premi kepada penggugat dikarenakan beberapa poin yang di eksepsi- 


\section{Jurnal Cakrawala Hukum, Volume 11 No. 1 April 2020}

ISSN PRINT 2356-4962 ISSN ONLINE 2598-6538

kan tergugat tidak terbukti dan di pastikan melakukan wanprestasi. Oleh karena itu dalam vonis ini menghukum perusahaan untuk membayarkan premi asuransi sesuai diagnosa kritis sebesar Rp. 150.000.000 dan premi yang harusnya dibayarkan. Pada putusan tersebut yang paling dibebankan untuk kewajiban bertanggungjawab adalah tergugat 1 (T1) sebagai perusahaan asuransi. Sedangkan tergugat 2 (T2) sebagai perbankan hanya diberikan kewajiban untuk biaya perkara.

Berdasarkan putusan hakim tersebut dapat diketahui bahwa perusahaan asuransi merupakan pelaku dalam melakukan wanprestasi sedangkan perbankan merupakan pelaku utama serta gerbang dalam membuka akses pembiayaan melalui kartu kredit. Hal ini terungkap bahwa dalam pernyataan posita pihak asuransi dan perbankan bekerja sama. Identitas penggugat baik berupa nomor handphone maupun kelayakan pembayaran diberikan kepada pihak ketiga. Modus pendekatan menggunakan kedekatan personal dari tergugat pertama yaitu perbankan.

Petitum dalam perkara di atas juga mencantumkan permintaan penutupan atas perusahaan asuransi yang berakibat kerugian pada konsumen. Pada petitum memang bukan kewenangan dari pengadilan negeri untuk mencabut izin operasional. Kewenangan Otoritas Jasa Keuangan setidaknya mampu mencabut izin operasional dari PUJK yang benar-benar tidak mempunyai itikad baik dalam mengelola perusahaan dan anak perusahaannya.

Modus korporasi yang lain adalah dengan menyalahgunakan keadaan. Modus ini sering dikenal dengan istilah Misbruik van Omstadigheden. Padahal dari segi aturan sudah sangat jelas dalam melindungi konsumen dari celah ini yaitu Peratuan Otoritas Jasa Keuangan No. 1/POJK.07/2013 yang memuat di dalamnya bahwa pelaku usaha dalam ini termasuk menggunakan jasa telemarketing untuk tidak menawarkan produknya di saat konsumen tidak sedang dalam mengambil keputusan.
Celah dari aturan ini adalah bagaimana membuktikan konsumen tidak sedang berada dalam posisi tersebut. Celah ini akan banyak dimanfaatkan oleh telemarketing sebab hanya suara saja yang dapat dibuktikan, sedangkan keadaan tertentu dapat dimanipulasi dengan menghilangkan distorsi suara dan metode lainnya.

Terdapat beberapa tipe tentang penyalahgunaan kedaan antara lain (Henry, 1992), yaitu:

a. Penyalahgunaan keadaan karena keunggulan ekonomi dari satu pihak terhadap pihak lain;

b. Penyalahgunaan keadaan karena salah satu pihak lebih unggul dari pihak lain ditinjau dari sisi psikologis (geestelijke overwicht);

c. Penyalahgunaan karena keadaan darurat (noodtoestand), namun tipe ketiga ini masih banyak yang mengklasifikasikannya ke dalam tipe yang pertama karena adanya keunggulanekonomi.

Perkembangan di dunia hukum, cacat kehendak juga terjadi dalam bentuk penyalahgunaan keadaan atau misbruik van omstandigheden/undue influence (Herlien, 2008). Pernah tejadi di Negara Belanda, dalam Pasal 3 : 44 NBW pada Januari 1992 di dalam perjanjian yang disepakati dapat dibatalkan apabila salah satu pihak yang dalam melakukan perjanjian, berada dalam keadaan darurat, terpaksa atau dalam keadaan di mana pihak lawannya mempunyai keadaan psikologis yang lebih kuat sehingga mengakibatkan menyalahgunakan keadaan tersebut dalam membuat perjanjian.

Awal mula adanya undue influence yaitu pada kebebasan berkontrak yang diberikan pada Kitab Undang-Undang Hukum Perdata. Seringkali kebebasan berkontrak ini ditafsirkan oleh para pihak secara berlebihan tanpa memperhatikan batasan dan kaidah yang berlaku. Pemikiran dasar para pelaku perjanjian hanya menganggap bahwa asas pacta sun servanda yang disetarakan atau berlaku sebagai Undang-Undang ini mampu menandingi Undang-Undang yang ada. Kebebasan berkontrak 
memungkinkan menimbulkan ketidakadilan yang disebabkan adanya posisi tawar (bargaining position) yang tidak berimbang dari para pihak yang menutup perjanjian. Posisi tawar ini lebih ke arah nilai kebutuhan, siapa yang paling butuh dialah yang memiliki possi tawar lebih rendah. Seringkali posisi tawar semacam ini menyebabkan pihak dengan posisi tawar yang lebih tinggi memberikan otoriter kemauannya kepada pihak lawannya dalam perjanjian.

Penyalahgunaan ini merupakan bentuk pergeseran peran telemarketing, yang semula hanya berbatas di marketing beralih fungsi kepada pembuat kontrak atau perpanjangan perusahaan dalam melegalkan kontrak. Harusnya ada standar kebijakan dalam pengaturan telemarketing yang membedakan atas dasar permintaan dan atas dasar penawaran. Jika konsumen mengikatkan diri dalam suatu perjanjian atas dasar permintaan, maka suatu perjajian elektronik tersebut mempunyai kekuatan yang cukup. Hal ini didukung dengan disebutkannya resiko-resiko yang diberikan dalam produk atau jasanya. Jika konsumen justru terikat atas dasar penawaran dari petugas telemarketing, inilah yang justru menjadi sumber masalah dalam segala jasa keuangan, sebab telemarketing dalam menjalankan promosinya tidak disebutkan secara holistik resiko dan bahkan dengan caracara yangmemaksa.

Penerapan rumusan suatu pasal peraturan di Indonesia melalui konsep mala in se dan mal in prohibitia. Kedua tindakan ini membedakan jenis sanksinya Tindakan yang dilakukan seseorang diduga melakukan kejahatan atau pelanggaran dapat diuji berdasarkan kaedah hukum yang dilanggar apakah tindakan seseorang tersebut termasuk kategori tindakan yang merupakan mala in se atau perbuatan yang merupakan mala in prohibita.

Tindakan yang termasuk mala in se, adalah perbuatan yang melawan hukum, ada atau tidak ada peraturan yang melarangnya misalnya mencuri, menipu, membunuh, dan sebagainya. Sedangkan perbuatan yang disebut sebagai mala in prohibita adalah perbuatan yang dinyatakan melanggar hukum apabila ada aturan yang melarangnya misalnya pelanggaran lalu lintas, aturan-aturan administrasi suatu lembaga. Apabila tindakan seseorang itu termasuk perbuatan mala in prohibita, sebanarnya adalah pelanggaran aturan administrasi dan tidak dapat dikenakan hukuman pidana melainkan hanya tindakan administratif.

Perlu diketahui bahwa sanksi administratif hanya berlaku pada jenis pelanggaran, yang artinya dilakukan dengan mal in prohibitia. Sanksi administratif seperti pencabutan Ijin (KTUN), teguran lisan dan tertulis, bahkan yang tertinggi adalah pidana denda atau kurungan. Berbeda dengan kejahatan, yang dalam hal ini mala in se, yang termasuk kategori kejahatan yang dapat diberikan sanksi pidana. Pada Indonesia rata-rata kepada kejahatan korporasi hanya terbatas pada mala in prohibita, dimana hanya diberikan sanksi administratif.

Kekuatan bukti perekaman hanya bersandar berdasarkan Undang-Undang ITE tanpa memperhatikan kekuatan-kekuatan alat bukti yang lainnya. Perbandingan kekuatan alat bukti seperti akta bawah tangan dan akta otentik akan jelas sangat berbeda di dalam menyelesaikan suatu perkara. Hal seperti ini seharusnya diperhatikan mengingat era digital sekarang membutuhkan pembaharuan hukum di sektor cyber. Ketertinggalan hukum di dalam sistem civil law akan semakin tertinggal dengan laju-laju perkembangan kebutuhan manusia, dimana proses formalisme menjadi titik tolak dalam sistem ini.

2) Putusan Pengadilan tingkat Banding Nomor No. 75/Pdt/2018/PT Mdn dengan para pihak Pribadi Barus VS Bank Mandiri, Tbk

Putusan ini merupakan salah satu bahan yang dapat dianalisis merupakan dampak dari dunia marketing. Pada putusan ini justru menghukum konsumen sebagai penggugat. Alasan da- 


\section{Jurnal Cakrawala Hukum, Volume 11 No. 1 April 2020}

ISSN PRINT 2356-4962 ISSN ONLINE 2598-6538

lam pengabulan pembanding yaitu Bank Mandiri mampu membuktikan adanya unsur kesengajaan wanprestasi. Putusan ini membatalkan putusan pengadilan tingkat pertama dengan dasar judex factie. Posisi dan peran telemarketing dalam kasus ini bukan sebagai pengikat perjanjian di awal, namun sebagai penguat layanan yang telah ditawarkan.

Bahan pertimbangan pengadilan tinggi medan membatalkan putusan hakim sebelumnya adalah pada pembuktian yang diberikan bank mandiri secara valid bukan hanya dari transaksi telemarketing, namun dari surat elektronik dan jejak rekam digital yang dikirmkan kepada nasabah. Pertimbangan hakim ini jelas memperkuat bahwa alat bukti telemarketing bukanlah kuat dan satu-satunya yang menjadi bukti persidangan, namun perlu diperkuat melalui bukti digital lainnya.

\section{Simpulan}

Peran telemarketing dalam penyedia jasa keuangan sudah mulai disalahgunakan. Idealnya telemarketing hanya sebatas pemasaran, bukan sebagai pembuat kontrak. Pergeseran paradigma peran telemarketing disebabkan tuntutan perusahaa itu sendiri yang disebabkan adanya caracara memaksa kepada konsumen bahkan dengan melalui keadaan yang disalahgunakan untuk memulai suatu perjanjan. Peran dari telemarketing memerlukan pengawasan ketat, bukan hanya dari regulasi. Hal ini harus diberikan pandangan oleh pembuat aturan bahwa bukti rekaman dari telemarketing bukanlah yang terkuat sebagaimana akta otentik dalam dokumen perjanjian.

\section{Daftar pustaka}

Budiono, Herlien. 2008. Kumpulan Tulisan Hukum Perdata di Bidang Kenotariatan. Bandung. Citra Aditya Bakti.
Firdausi, Firman. Eksistensi 'White Collar Crime' Di Indonesia: Kajian Kriminologi Menemukan Upaya Preventif, https://jurnal.unitri.ac.id/index.php/ reformasi/article/view/680 (diakses tanggal 10 Juni 2019).

Hagan, J. L. 1985. Modern Criminology: Crime, Criminal Behavior and its Control. Michigan University. McGraw-Hill.

https://id.tellows.net (diakses tanggal 1 Oktober 2019).

Ibrahim, Johnny. 2007. Teori dan Metodologi Penelitian Hukum Normatif. Malang. Bayu Medali.

Kitab Undang - Undang Hukum Perdata.

Kitab Undang-Undang Hukum Acara Perdata (HIR/ Herzien Inlandsch Reglement).

Laila, K. (2017). Perlindungan hukum terhadap konsumen atas iklan yang melanggar tata cara periklanan. Jurnal Cakrawala Hukum, 8(1), 64-74. doi:10.26905/idjch.v8i1.1732.

Mahkamah Agung. https://putusan.mahkamahagung.go.id/ putusan (diakses tanggal 10 Juni 2019).

Marzuki, Peter Mahmud. 2005. Penelitian Hukum. Jakarta. Kencana.

Nuha, M. (2018). Pertanggungjawaban Pidana Korporasi terhadap Tindak Pidana yang Dilakukan oleh Karyawan Marketing. Jurnal Cakrawala Hukum, 9(1), 99-106. doi:10.26905/idjch.v9i1.2192.

Panggabean, Henry P. 1992. Penyalahgunaan Keadaan (Misbruik van Omstandigheden) Sebagai Alasan Baru Untuk Pembatalan Perjanjian (Berbagai Perkembangan Hukum di Belanda. Yogyakarta. Liberty.

Paramarta, Nabhila Palupi. Analisis Yuridis Mengenai Rekaman Pembicaraan Telepon Sebagai Alat Bukti dalam Perjanjian Asuransi Melalui Telemarketing (Ditinjau dari Undang-Undang no. 11 Tahun 2008 tentang Informasi dan Transaksi Elektronik). http:/ /hukum.studentjournal.ub.ac.id/index.php/hukum/article/view/777 (diakses tanggal 2 Mei 2019).

Peratuan Otoritas Jasa Keuangan No. 1/POJK.07/2013 tentang Perlindungan Konsumen Sektor Jasa Keuangan. 


\section{Analisis yuridis-normatif terhadap peran dan tindakan telemarketing dalam transaksi digital}

Indah Rahmawati

Raily, Michael., dkk. Polisi Dalami Dugaan Pihak Bank terlibat Kasus Pencurian Data Nasabah. https:// katadata.co.id/ berita/2017/08/25/polisidalami-dugaan-pihak-bank-terlibat-kasuspencurian-data-nasabah (diakses tanggal 14 Juni 2019).

Supriyatna, Iwan. Pencurian Data Nasabah Carut-Marut Perbankan. https://money.kompas.com/read/ 2017/04/04/070000026/pencurian.data. nasabah.potret.carut-marut.perbankan.?page=all (diakses tanggal 10 Juni 2019).

Surat Edaran Otoritas Jasa Keuangan Nomor 12/ SEOJK.07/2014.
Tanya, Bernard L., dkk. 2013. Teori Hukum : Strategi tertib Manusia. Yogyakarta. Genta Publisihing.

Undang-Undang Republik Indonesia Nomor 10 Tahun 1998 Tentang Perbankan.

Undang-Undang Republik Indonesia Nomor 11 Tahun 2008 Tentang Informasi dan Transaksi Elektronik.

Undang-Undang Republik Indonesia Nomor 8 Tahun 1992 Tentang Perlindungan konsumen.

Yanuareksa, Robby. Penerapan UU ITE dan UU Perlindungan Konsumen Bagi Transaksi Telemarketing. https://ejournal3.undip.ac.id (diakses tanggal 1 Oktober 2019). 